\title{
Analysis of the Relationship between Women's Participation and the Rate of Corruption in the Post-Soviet States
}

\author{
Bektas Baktybayev ${ }^{*}$ \\ Graduate School of Public Policy, Nazarbayev University, Kabanbay batyr Ave., 53, Block C3 \\ (42) Astana, 010000, Republic of Kazakhstan.
}

Received: 2020-02-27; Accepted: 2020-04-27; Published: 2020-04-30

\begin{abstract}
Corruption remains one of the main problems of Post-Soviet states. Georgia, Belarus, Lithuania, and Latvia are doing relatively well compared to other Post-Soviet states. Popular explanations for high corruption rates are underdevelopment of democratic institutions and the limitation of human rights. However, the lack of women's participation can be also another factor that could explain the widespread corruption level. According to popular stereotypes, women are considered as more honest and "fairer" gender, which has an impact on the decrease in corruption rate. There is a belief that women have a perception of risk aversion which makes them less likely to engage in corrupt activities. There is no consensus regarding whether women's participation has an effect on reducing corruption. The purpose of this paper is to test to what extent women's participation in parliament, school and or with tertiary education, labor force affects corruption rate in Post-Soviet states. The SPSS software was used to assess a relationship between aforementioned variables. According to findings, there is a strong, positive, and statistically significant impact of women enrollment in school and/or with tertiary education on a country's score in the Corruption Perception Index. I argue that promoting women's education is the best way to lower corruption in the post-Soviet states.
\end{abstract}

Keywords: Women's Participation; Corruption Rate; Post-Soviet States; Corruption Perception Index

How to Cite: Baktybayev, B. (2020). Analysis of the relationship between women's participation and the rate of corruption in the Post-Soviet states. Journal of Contemporary Governance and Public Policy, 1(1), 1-11.

Permalink/DOI: https://doi.org/10.46507/jcgpp.v1i1.3 


\section{Introduction}

According to the corruption perception index (CPI) of transparency international Georgia, Belarus, Lithuania, and Latvia are in the list of Post-Soviet states that did better than the global average (Golos Ameriki, 2019)(Transparency International, 2019).At the same time, Russia and Central Asian states are far from the global average (Azattyq, 2019). Even though these countries were previously part of the large country, their scores significantly vary between each other. There are various reasons which can explain such differences in CPI. One of these factors is female's participation in politics and the economy. In this research paper, I am going to compare the relationship between women's participation and corruption rate. Particularly, I am going to test the impact of women's participation in the parliament, women's share in school and or with tertiary education, women's share in the labor force on corruption rate. I will use a simple regression analysis to test corruption-related theories in the Post-Soviet context. I found that not all theories are applicable in the Post-Soviet space. This research will hopefully help to fill the gap in the literature. It is because there is no much research that analyzes the factors and reasons that lead to corruption in all Post-Soviet states together.

In the literature review section, I would like to share with you what other scholars have said about the relationship between women's participation and corruption. In this section, I will write about women's participation in parliament, labor force, and education. Then in the methodology section, I will explain how I will test the relationship between independent and dependent variables. In the next sections, I will provide results and discuss them. Finally, I make a conclusion that not all theories are applicable in the PostSoviet context.

Various theories can explain women's impact on the level of corruption. For example, liberal democracy theory tells that corruption does not depend on gender and there is a spurious relationship between gender and corruption (Bauhr, Charron, \& Wängnerud, 2019). Liberal democracy leads to a higher number of women elected as well as good governance (Wängnerud, 2012, p. 234). According to gender differences, sex roles theory, gender has a direct impact on corruption (Wängnerud, 2012). This theory tells that there are differences between women and men's behaviors and mostly men dominate criminal activities (Wängnerud, 2012).

There is also the opportunity structure theory, which tells about an indirect relationship between gender and corruption (Wängnerud, 2012, p. 234). Women tend to be less involved in public affairs due to family affairs and women may be excluded from "old boys networks" (Wängnerud, 2012 , p. 234). The next rationality perspective theory tells about gender roles at the citizen level and decisionmaking arenas. (Wängnerud, 2012, p. 244). At the citizen level, women are willing to avoid corrupt transactions because women have fewer assets and women considered as a society's subordinate group (Wängnerud, 2012, p. 244). In the decision-making arenas of rationality perspective theory, there is an indirect relationship between gender and corruption since women are interested to uphold alternative bases of power (Wängnerud, 2012, p. 244). 
That is why women are not interested in corruption activities (Wängnerud, 2012, p. 244).

Women's participation at different levels has a different impact on corruption. For example, there is no consensus regarding the correlation between women's participation in parliament and the level of corruption. Esarey and Schwindt-Bayer (2019) have found that women's greater representation in parliament is correlated with the lower corruption rate. They also found that corruption will result in fewer women's participation in government (Esarey \& SchwindtBayer, 2019). Their findings were based on the analysis of partial and full democracies between 1990 and 2010 (Esarey \& Schwindt-Bayer, 2019, p. 1715).

Jha and Sarangi (2018) also found and provided robust evidence that women's presence in parliament causes a decrease in corruption. At the same time, they did not find a positive relationship between other measures of female participation and economic activities (Jha \& Sarangi, 2018, p. 219). According to their findings, the presence of women in the labor force, in clerical positions, and senior-level, decision-making positions do not necessarily lead to lower corruption (Jha \& Sarangi, 2018, p. 219). Jha and Sarangi (2018, p. 231) argued that only presence in parliament, the policymaking process, can reduce the corruption rate.

Pelizzo (2013) findings also support the claim that women's greater presence in parliament is important for the countries. Pelizzo (2013) analyzed the relationship between gender and oversight effectiveness. Their main finding is that parliaments with a higher share of women are characterized by more effective legislative oversight (Pelizzo, 2013). When they added the form of government to regression, the relationship between gender and legislative oversight effectiveness remained statistically significant (Pelizzo, 2013). They concluded that promoting gender equality in the parliaments will lead to better effectiveness of legislative oversight (Pelizzo, 2013).

In this research project I am going to test the following first hypothesis:

\section{The greater number of women in the parliaments leads to lower corruption.}

It is also interesting to analyze the relationship between gender and education. Melgar et al. (2010) have found that people's education level affects their corruption perception. For example, people with a secondary level of education are going to have lower corruption rate (Melgar et al., 2010, p. 125). They explained it with the fact that there is a positive relationship between "access to information and the capability to process it" (Melgar et al., 2010, p. 125). Thus, more educated people have the skills to find and analyze corruption-related information (Melgar et al., 2010, p. 125).

Branisa et al. (2013, p. 261) found that "lower female secondary education, higher fertility rates, higher child mortality, and a higher perceived level of corruption in a country" are social institutions related to gender inequality. They argued that social institutions need to be considered to see the differences in important development outcomes (Branisa et al., 2013, p. 261). Branisa et al. (2013, p. 253) also found that countries which discourage freedom of women to participate in social life, tend to have higher rates of corruption. Thus, it is important to analyze how women are treated in different societies in order to develop 
gendered development outcomes (Branisa et al., 2013, p. 253).

According to the various theories, it is important to provide equal universal education. The provision of widespread education is important to reach greater gender equality (Uslaner \& Rothstein, 2016). It is because there is a strong relationship between gender equality and a lower level of corruption (Uslaner \& Rothstein, 2016, p. 7). The relationship remains constant even other variables get added and is applicable in corrupt countries such as Mexico (Uslaner \& Rothstein, 2012). It is important to spread the provision of equal education all over the world since this practice is not accepted everywhere (Uslaner \& Rothstein, 2012, p. 7).

The second hypothesis is going to be in the following way:

\section{The higher the share of the women in the school and or with tertiary education, the less corruption will be.}

Some scholars suggest that there is a direct relationship between gender in the labor force and the corruption rate. Swamy et al. (2001) have found that the greater share of women in the parliaments, senior positions, and labor force has a direct impact on lower corruption rates. One of the explanations here is that women owners or managers offer fewer bribes compared to male counterparts (Swamy et al., 2001, p. 36). Another reason is that women may pay fewer bribes because they are not always part of "old boy networks" (Swamy et al., 2001, p. 36). Authors also argued that women did not "learn" how to "bribe" since they were previously less engaged in individual or collective experience of the labor force (Swamy et al., 2013, p. 36).
Samimi \& Hosseinmardi (2011) findings are consistent with the aforementioned authors. They have analyzed women's participation in parliaments and the labor force of 25 developing countries (Samimi \& Hosseinmardi, 2011, p. 725). They found a negative relationship between corruption and participation of women in the labor force as well as between corruption and the share of women in the parliaments (Samimi \& Hosseinmardi, 2011, p. 725). Neudorfer (2016) highlighted the importance of women in the labor force. He found that countries with a large public sector that have a high share of working women are less corrupt than countries with a fewer share of working women (Neudorfer, 2016, p. 190). Neuforder (2016, p. 194) explained it with the fact that employed women demand better education and working opportunities for other women and their children. Thus, they create opportunities for other women to go to work (Neuforder, 2016, p. 194).

The increase in the women's share leads to an increase in demand in public goods as well as total revenue due to the additional revenue from women's taxes (Neuforder, 2016, p. 194). As government consumption increases because of the greater of women in the labor force, the spending on private spending, which can lead to corrupt activities, will decrease (Neuforder, 2016, p. 206). Neuforder (2016, p. 197) provided real examples from Finland and Sudan. Finland is a country with a large female labor force (47.92 percent) has a very low corruption rate (Neuforder, 2016, p. 194). At the same time, Sudan has 10.9 percent of female share in the labor force as well as a very high level of corruption (Neuforder, 2016, p. 194). 
Bauhr et al. (2019) analyzed women's representation in locally elected assemblies and their impact on corruption. They found that elected women tend to promote public services directed to benefit traditionally female-oriented sectors, such as healthcare and education (Bauhr et al., 2019, p. 1060). Additionally, elected women aim to "breakup of male-dominated clientelist networks" (Bauhr et al., 2019, p. 1060). These two factors lead to a decrease in both petty and grand corruption (Bauhr et al., 2019, p. 1060).

The third hypothesis is going test relationship between gender and labor force:

\section{Greater the number of women in the labor force, lower the corruption rate}

In contrast to the aforementioned findings, some authors do not support the claim of the relationship between gender and corruption. Debsky et al. (2018) have found that the greater representation in business and politics does not lead to a lower corruption rate. They did not find a statistically or economically significant relationship between gender and corruption when they considered country-specific timeinvariant factors (Debsky et al., 2018, p. 535). Initially, they found a positive relationship between women's participation in politics and labor force and politics \& lower level of corruption (Debsky et al., 2018, p. 535). However, then they added culture-related variables, such as culture, geography, and institutions, the relationship became spurious (Debsky et al., 2018, p. 535). Thus, the female's participation does not directly link to a lower level of corruption (Debsky et al., 2018, p. 536).

\section{Research Methods}

In this paper, I will use SPSS software to test my three hypotheses. I aim to test the correlation between women's seats in parliament, education, the labor force (independent variables) \& corruption rates. The data for independent variables will be taken world bank development indicators (The World Bank, 2019). The data for the dependent variable will be taken from the CPI of each country (Transparency International, 2019b). I am going to test the correlation between independent and dependent variables for the 2018 year.

\begin{tabular}{|c|c|c|c|c|c|c|}
\hline $\begin{array}{l}\text { Alpbatecic } \\
\text { al order }\end{array}$ & $\begin{array}{l}\text { Post-Soviet } \\
\text { states }\end{array}$ & $\begin{array}{l}\text { Women } \\
\text { in } \\
\text { parliame } \\
\text { nts }(\%) \\
2018\end{array}$ & $\begin{array}{l}\text { CPI } \\
(201 \\
8)\end{array}$ & $\begin{array}{l}\text { Unemploym } \\
\text { ent }(\%)\end{array}$ & $\begin{array}{l}\text { Labor } \\
\text { force, } \\
\text { female (\% } \\
\text { of total } \\
\text { labor } \\
\text { force) }\end{array}$ & $\begin{array}{l}\text { School } \\
\text { enrollment, } \\
\text { tertiary, } \\
\text { female (\% } \\
\text { gross) }\end{array}$ \\
\hline 1 & Armenia & 18 & 35 & 17,899 & 45,991 & 62,648 \\
\hline 2 & Azerbaijan & 17 & 25 & 6,054 & 48,71 & 29,693 \\
\hline 3 & Belarus & 35 & 44 & 4,139 & 49,665 & 95,092 \\
\hline 4 & Estonia & 27 & 73 & 5,132 & 48,269 & 84,824 \\
\hline 5 & Georgia & 16 & 58 & 12,677 & 45,706 & $\begin{array}{l}63,738 \\
(2017)\end{array}$ \\
\hline
\end{tabular}




\begin{tabular}{|c|c|c|c|c|c|c|}
\hline 6 & Kazakhstan & 27 & 31 & 5,625 & 48,435 & 60,033 \\
\hline 7 & Kyrgyzstan & 19 & 29 & 8,863 & 40,042 & 46,735 \\
\hline 8 & Latvia & 16 & 58 & 6,799 & 49,987 & $\begin{array}{l}105,059 \\
(2017)\end{array}$ \\
\hline 9 & Lithuania & 21 & 59 & 5,513 & 50,512 & $\begin{array}{l}84,001 \\
(2017)\end{array}$ \\
\hline 10 & Moldova & 23 & 33 & 2,975 & 48,703 & 45,719 \\
\hline 11 & Russia & 16 & 28 & 4,569 & 48,486 & $\begin{array}{l}89,116 \\
(2017)\end{array}$ \\
\hline 12 & Tajikistan & 19 & 25 & 9,743 & 31,943 & $\begin{array}{l}26,854 \\
(2017)\end{array}$ \\
\hline 13 & $\begin{array}{l}\text { Turkmenist } \\
\text { an }\end{array}$ & 25 & 20 & 2,114 & 41,657 & $\begin{array}{l}6,196 \\
(2014 !)\end{array}$ \\
\hline 14 & Ukraine & 12 & 32 & 8,139 & 47,275 & 89 (2014!) \\
\hline 15 & Uzbekistan & 16 & 23 & 5,018 & 41,371 & 8 \\
\hline $\begin{array}{l}\text { Re: } \\
\text { by } \\
\text { bet }\end{array}$ & $\begin{array}{l}\text { tested th } \\
\text { share of }\end{array}$ & & & \multicolumn{3}{|c|}{$\begin{array}{l}\text { perception index. I did not find a } \\
\text { positive relationship between the } \\
\text { share of women in parliaments and } \\
\text { the corruption rate among Post- } \\
\text { Soviet } \\
\text { countries. }\end{array}$} \\
\hline
\end{tabular}

in parliament and the corruption

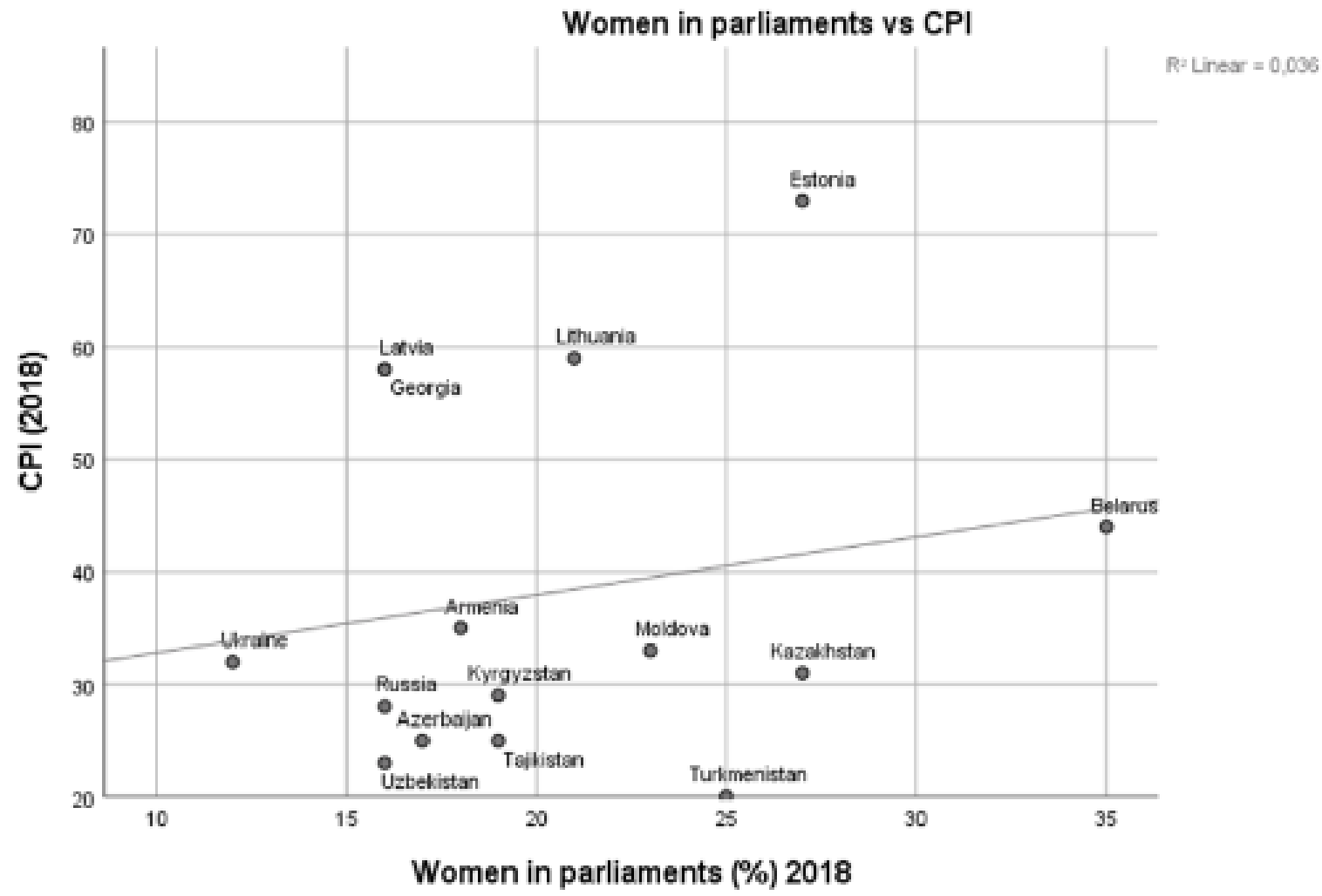

According to the graph, Hypothesis 1 is rejected. 


\begin{tabular}{|c|c|c|c|c|c|c|}
\hline \multicolumn{7}{|c|}{ ANOVA $^{a}$} \\
\hline Model & & $\begin{array}{l}\text { Sum of } \\
\text { Squares }\end{array}$ & df & Mean Square & $\mathrm{F}$ & Sig. \\
\hline \multirow[t]{3}{*}{1} & Regression & 131,258 & 1 & 131,258 & 480 &, $501^{b}$ \\
\hline & Residual & 3557,142 & 13 & 273,626 & & \\
\hline & Total & 3688,400 & 14 & & & \\
\hline
\end{tabular}

a. Dependent Variable: CPI (2018)

b. Predictors: (Constant), Women in parliaments (\%) 2018

\begin{tabular}{|c|c|c|c|c|c|c|c|c|}
\hline \multicolumn{9}{|c|}{ Coefficients $^{a}$} \\
\hline \multirow[b]{2}{*}{ Model } & & \multicolumn{2}{|c|}{ Unstandardized Coefficients } & \multirow{2}{*}{$\begin{array}{c}\text { Standardized } \\
\text { Coefficients } \\
\text { Beta }\end{array}$} & \multirow[b]{2}{*}{$t$} & \multirow[b]{2}{*}{ Sig. } & \multicolumn{2}{|c|}{$95,0 \%$ Confidence Interval for B } \\
\hline & & B & Std. Error & & & & Lower Bound & Upper Bound \\
\hline \multirow[t]{2}{*}{1} & (Constant) & 27,690 & 15,765 & & 1,756 & .103 & $-6,367$ & 61,747 \\
\hline & $\begin{array}{l}\text { Women in parliaments } \\
\text { (\%) } 2018\end{array}$ & .514 & .741 & .189 &, 693 & .501 & $-1,088$ & 2,115 \\
\hline
\end{tabular}

a. Dependent Variable: CPI (2018)

$\mathrm{P}=0.501>0.05$, that is why $\mathrm{H} 1$ is rejected.

Then I tested hypothesis 2.

\section{Hypothesis 2}

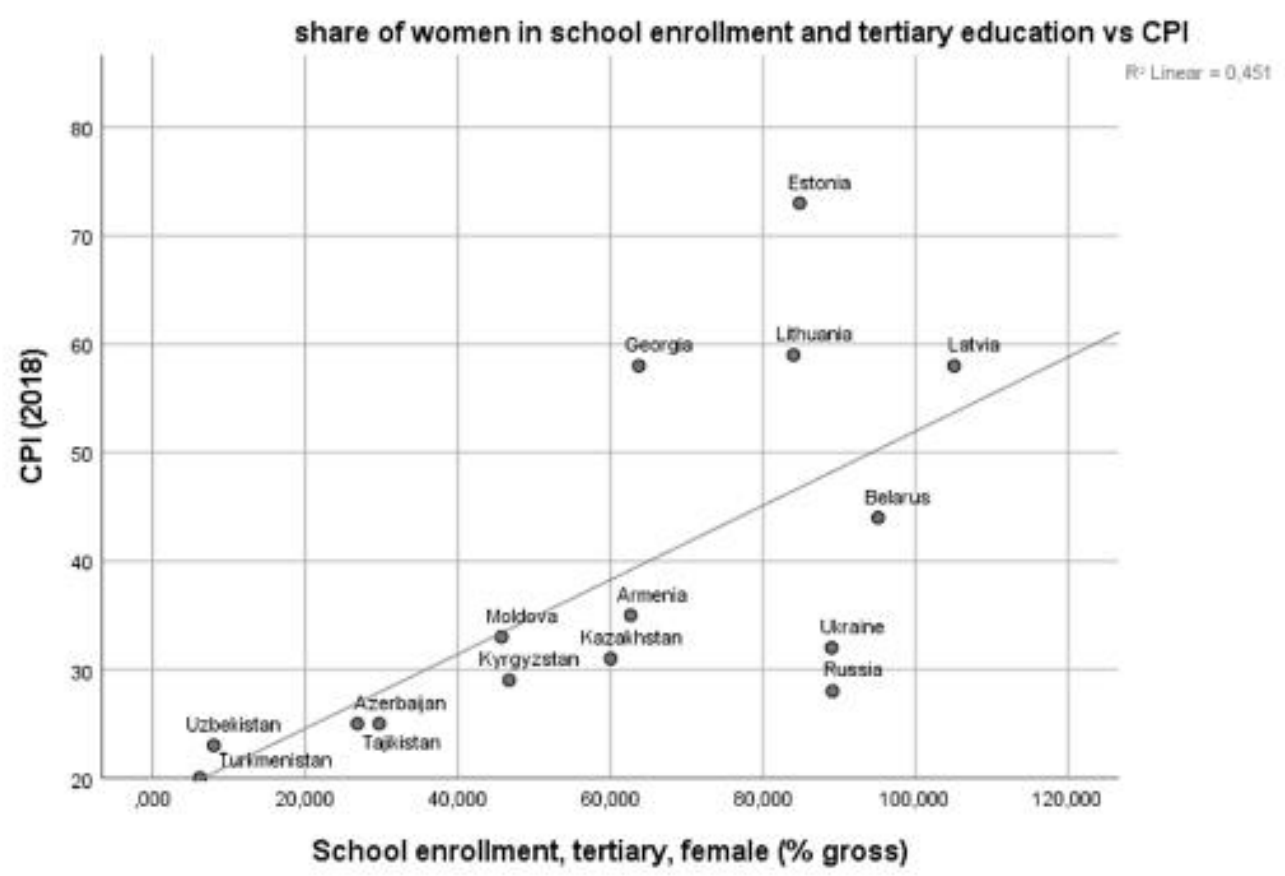

Here I will retain Hypothesis 2 since there is a positive relationship between the share of women in school enrollment and tertiary education and CPI. $\mathrm{p}=0.006<0.05(95 \% \mathrm{CI})$ I retain the null hypothesis.

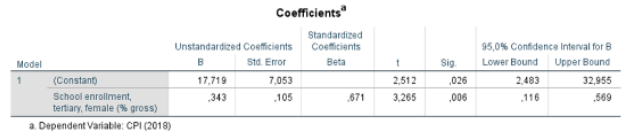




\begin{tabular}{|c|c|c|c|c|c|c|}
\hline \multicolumn{7}{|c|}{ ANOVA $^{a}$} \\
\hline \multicolumn{2}{|c|}{ Model } & $\begin{array}{l}\text { Sum of } \\
\text { Squares }\end{array}$ & df & Mean Square & $\mathrm{F}$ & Sig. \\
\hline \multirow[t]{3}{*}{1} & Regression & 1661,878 & 1 & 1661,878 & 10,661 &, $006^{\mathrm{b}}$ \\
\hline & Residual & 2026,522 & 13 & 155,886 & & \\
\hline & Total & 3688,400 & 14 & & & \\
\hline
\end{tabular}

a. Dependent Variable: CPI (2018)

b. Predictors: (Constant), School enrollment, tertiary, female ( $\%$ gross)

\section{Hypothesis 3}

Finally, I tested the relationship between the share of women in the labor force and the corruption rate in Post-Soviet countries.

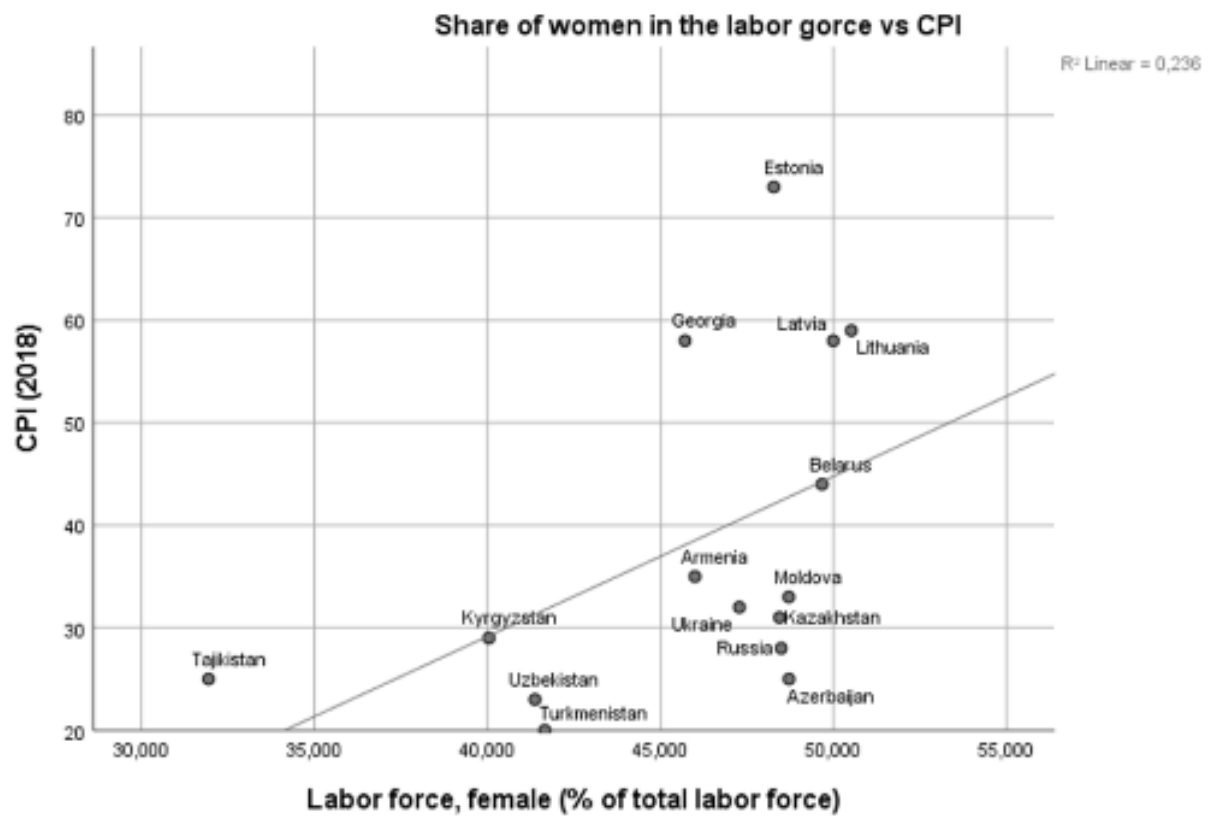

According to the graph, I will reject Hypothesis 3. There is no statistically significant relationship between the enrollment and tertiary education \& CPI. $\mathrm{p}=0.067>0.05$. I reject the null share of women in school hypothesis.

\begin{tabular}{|c|c|c|c|c|c|c|}
\hline \multicolumn{7}{|c|}{ ANOVA $^{a}$} \\
\hline \multicolumn{2}{|l|}{ Model } & $\begin{array}{l}\text { Sum of } \\
\text { Squares }\end{array}$ & df & Mean Square & $\mathrm{F}$ & Sig. \\
\hline \multirow[t]{3}{*}{1} & Regression & 869,527 & 1 & 869,527 & 4,010 & $.067^{b}$ \\
\hline & Residual & 2818,873 & 13 & 216,836 & & \\
\hline & Total & 3688,400 & 14 & & & \\
\hline
\end{tabular}

a. Dependent Variable: CPI (2018)

b. Predictors: (Constant), Labor force, female ( $\%$ of total labor force) 


\begin{tabular}{|c|c|c|c|c|c|c|c|c|}
\hline \multicolumn{9}{|c|}{ Coefficients $^{a}$} \\
\hline \multirow[b]{2}{*}{ Model } & & \multicolumn{2}{|c|}{ Unstandardized Coefficients } & \multirow{2}{*}{$\begin{array}{c}\text { Standardized } \\
\text { Coefficients } \\
\text { Beta }\end{array}$} & \multirow[b]{2}{*}{$t$} & \multirow[b]{2}{*}{ Sig. } & \multicolumn{2}{|c|}{$95,0 \%$ Confidence Interval for $B$} \\
\hline & & B & Std. Error & & & & Lower Bound & Upper Bound \\
\hline \multirow[t]{2}{*}{1} & (Constant) & $-33,354$ & 35,934 & & .928 & 370 & $-110,983$ & 44,276 \\
\hline & $\begin{array}{l}\text { Labor force, female ( } \% \text { of } \\
\text { total labor force) }\end{array}$ & 1,563 & .780 & .486 & 2,003 & .067 &,- 123 & 3,249 \\
\hline
\end{tabular}

The first hypothesis regarding the relationship between the greater share of women's seats in parliaments and the lower corruption rate was rejected. The possible explanation here is that women are not enough in parliaments of the Post-Soviet states to make valuable contributions to government spending and decrease in corruption rate.

The second hypothesis regarding the share of women in school enrollment and tertiary education was retained. It means that findings are consistent with existent theories regarding women's education. Provision of equality in education equality is crucial in fighting corruption. Especially Central Asian states need to work on providing better access and more opportunities for women to study in higher education institutions.

The third hypothesis regarding the share of women in the labor force and corruption rate was rejected. The possible explanation can be the same as for the first hypothesis. The share of women in the labor force may not be so high to make a contribution to reducing corruption. Another problem here is how reliable the data is. Some countries may be interested in artificially increase the share of women in the labor force in order to have a better image both internally and internationally.

\section{Conclusion}

The purpose of the present article was to test whether and to what extent the level of corruption in post soviet states is affected by women's participation. The rationale for performing such an analysis is hat, as several studies have shown and as the international community has long believed, where women participate more, the political system works better, the quality of democracy is higher and corruption is lower.

Specifically I performed some statistical analyses to assess whether women's participation in the parliament, women's share in tertiary education, women's share in the labor force are related to and possibly responsible for corruption levels.

The scatterplots and the regression analyses presented in the paper reveal that women's participation in parliament has a positive but weak and statistically insignificant, impact on the Corruption Perception Index. With regard to the relationship between the score in the Corruption Perception Index and women's participation in the labor force, visual inspection of the scatterplot reveals the existence of a strong and positive association. The regression analysis confirms the results of the visual inspection as it shows that women's participation in the labor force is a strong and positive determinant of CPI score. But while one could regard the impact of this variable as significant, from a substantive point of view, the regression coefficient reveals that the impact of women's participation in the labor force is not a statistically significant determinant of corruption levels. With regard to the relationship between women's education and corruption, the 
analyses presented in the paper show that as the percentage of women enrolled in school and/or with tertiary education is a strong, positive, and statistically significant impact on a country's score in the Corruption Perception Index.

Our findings have clear policy implications. While women's participation in parliament and in the labor force should be encouraged, our findings show that the single most important step that countries should take to curb corruption, promote transparency, and secure good governance is to provide women with more and better education.

Educated women are the best line of defense against corruption and the most effective way to improve the quality of government. Investing in education is important, but it is more important to secure equal access to education and ensure that young women have access to higher education.

Other studies, in the future, may explore whether our findings and conclusion hold in other regions. But one thing is clear: promoting women's education is the best way to lower corruption in the post-Soviet states.

\section{Acknowledgements}

I would like to express my very great appreciation to Dr. Riccardo Pelizzo for his valuable and constructive suggestions during the planning and development of this paper.

\section{References}

Azattyq. (2019). Ryadom s Gabonom i Dzhibuti. Kazakhstan na 124$\mathrm{m}$ meste $\mathrm{v}$ Indekse vospriyatiya korruptsii. Retrieved March 12, 2020, from Azattyq website: https://rus.azattyq.org/a/kaza khstan-corruption- perceptions-indextransparency/29738036.html

Bauhr, M., Charron, N., \& Wängnerud, L. (2019). Exclusion or interests? Why females in elected office reduce petty and grand corruption. European Journal of Political Research, 58(4), 1043-1065.

Branisa, B., Klasen, S., \& Ziegler, M. (2013). Gender Inequality in Social Institutions and Gendered Development Outcomes. World Development, 45, 252-268. https://doi.org/10.1016/j.wor lddev.2012.12.003

Debski, J., Jetter, M., Mösle, S., \& Stadelmann, D. (2018). Gender and corruption: The neglected role of culture. European Journal of Political Economy, 55, 526-537.

Esarey, J., \& Schwindt-Bayer, L. A. (2019). Estimating causal relationships between women's representation in government and corruption. Comparative Political Studies, 52(11), 1713-1741.

Golos Ameriki. (2019). Transparency International otmechayet uspekh Gruzii v bor'be $\mathrm{s}$ korruptsiyey. Retrieved April 25, 2020, from Golos Ameriki website: https://www.golosameriki.ru/a/georgiatransparency-internationcorruptionindex/4763692.html

Jha, C. K., \& Sarangi, S. (2018). Women and corruption: What positions must they hold to make a difference? Journal of Economic Behavior \& Organization, 151, 219-233.

Melgar, N., Rossi, M., \& Smith, T. W. (2010). The Perception of Corruption. International Journal of Public Opinion Research, 22(1), 120-131. 
https://doi.org/10.1093/ijpor /edp058

Neudorfer, N. S. (2016). Gender and Graft: A Political Economy Argument about the Influence of Working Women on Political Corruption. Journal of Women, Politics \& Policy, 37(2), 190-216.

https://doi.org/10.1080/1554 477X.2016.1153337

Pelizzo. (2013). Women do it better! A key lesson in the study of legislative oversight. Retrieved January 20, 2020, from Agora Parl website: https://agoraparl.org/interact/blog/women -do-it-better-key-lesson-studylegislative-oversight

Samimi, A., \& Hosseinmardi, H. (2011). Gender and corruption: Evidence from selected developing countries. Middle-East Journal of Scientific Research, 9(6), 718727.

Swamy, A., Knack, S., Lee, Y., \& Azfar, O. (2001). Gender and corruption. Journal of Development Economics, 64(1), 25-55.

https://doi.org/10.1016/S030 4-3878(00)00123-1
The World Bank. (2019). World development indicators. Retrieved January 23, 2020, from The World Bank website: http://datatopics.worldbank.o $\mathrm{rg} /$ world-developmentindicators/

Transparency International. (2019). Eastern Europe \& Central Asia: weak checks and balances threaten anti-corruption efforts. Retrieved April 10, 2020, from Transparency International website: https://www.transparency.or g/news/feature/weak_checks_ and_balances_threaten_anti_co rruption_efforts_across_easter n_eu

Uslaner, E. M., \& Rothstein, B. (2016). The Historical Roots of Corruption: State Building, Economic Inequality, and Mass Education. Comparative Politics, 48(2), 227-248. https://doi.org/10.5129/0010 41516817037736

Wängnerud, L. (2012). Why women are less corrupt than men. In Good Government. Edward Elgar Publishing.

(C) 2020 by Autors. Submitted for possible open access publication under the terms and conditions of the Creative Commons Attribution (CC BY SA) license (https://creativecommons.org/licenses/by-sa/3.0/). 